\title{
Frequency of Diseases Occurrence in Poultry Production Cluster (PPC) and Non-PPC in Indonesia
}

\author{
Martindah $\mathrm{E}^{1}$, Ilham $\mathrm{N}^{2}$ \\ ${ }^{1}$ Indonesian Research Center for Veterinary Science \\ Jl. RE Martadinata No. 30, Bogor 16114, West Java, Indonesia \\ ${ }^{2}$ The Indonesian Center for Agriculture Socio Economic and Policy Studies \\ Jl. Tentara Pelajar, Blok Kompleks Pertanian No.3, Ciwaringin, Bogor 16124, West Java, Indonesia \\ emartindah@hotmail.com
}

\begin{abstract}
A study to determine the diseases occurrence and the effectiveness in controlling infectious disease on the small poultry producers was carried out in Poultry Production Clusters (PPC) and non-PPC in West Java Province, Indonesia. In the PPC, the farmers form a cluster in an area. Secondary and primary data were collected by using semi structured questionnaires, focus group discussions, epidemiology-related information and triangulated check on information. The results indicated education and working experiences of farmers in chicken farming were the important factors for making decisions and getting the best for raising the poultry farm. Education levels of the farmers range from 6 to 10 years and farmers' experience of poultry farming was 7 to 10 years. Farmers' efforts to prevent disease occurrence were not optimum, as prevention and disease control were part of the nucleus responsibilities. The level of diseases occurrence in both PPC and non-PPC was similar with a few variations, and mortality rate was less than 5\%. The diseases frequently found in PPC were slow growth syndrome and CRD, while in non-PPC was dominated by diarrhea. It is suggested that to reduce the disease occurrence, farm workers in PPC and nonPPC should implement some basic principle of biosecurity.
\end{abstract}

Key Words: Diseases, Occurrence, PPC, Non-PPC

\section{INTRODUCTION}

Poultry industry in Indonesia has made substantial progress in supporting government programs to provide employment, and the production of broilers contributes to nearly $66 \%$ of total national meat production (Ditjen PKH 2013). Poultry production constitutes a vital source of livelihood and is seen as an important pathway out of poverty in many rural people. It plays an important economic role and has strong impact on society, culture and tradition. Based on the production system, poultry industry in Indonesia is divided into 4 sectors e.i.: (1) Sectors 1 is an integrated poultry farm, strictly implement high levels of biosecurity; (2) Sector 2 is the commercial poultry farms that perform maintenance and apply biosecurity moderately; (3) Sector 3 is commercial farms (small farmers), implementing limited biosecurity resulting in contact with wild birds; and (4) Sector 4 is traditional farmers (back yard ), without implement biosecurity. The largest shares in terms of number of farmers involved are sectors 3 and 4 . These sectors have a lot of weakness in terms of animal health systems in comparison to sectors 1 and 2, so that both sectors are suceptible to get diseases. Adjid et al. (2006) informed that different production systems between sectors 3 and 4 also lead to different encountered disease problems.

The government of Indonesia paid great attention in developing small-scale poultry business, to reduce poverty and create employment opportunities. Small-scale poultry business is particularly vulnerable to economic changes as $90 \%$ of the input is imported and it is also susceptible to poultry diseases. In order to overcome this problem, small scale poultry business has been set up on Poultry Production Cluster (PPC) under partnerships 
with companies and has been accepted by rural communities (Ilham et al. 2013). The PPC's growth cannot be ignored as a provider of employment and income for the poor. Various policies to encourage the growth of PPC in rural areas have been established (Ilham 2015); as an example Village Poultry Farming (VPF) was formed in 2006. The VPF aims to develop poultry production centers in rural areas by applying good farming practices in an effort to suppress outbreaks of poultry diseases, particularly poultry producers in sector-4. The fact shows that these policies have not been able to solve the problems due to lack of sustain supervision.

Ilham et al. (2013) reported that currently, PPC in Indonesia occurs naturally as a result of the government policy in the past. Meanwhile, in Tiongkok (Wang et al. 2014) and in Thailand (Aengwanich 2014) the existence of PPC is created by the government's policy for restructuring the poultry farms. According to study on poultry farming conducted by Aengwanich et al. (2012) revealed that poultry production clusters (PPCs) in Thailand were composed of small-scale farmers and these poultry production clusters were defined as "areas of concentrated poultry production in rural areas usually separated from residential areas". In China, since 2003 the government issued various policies to promote PPC model to move small producers into the clusters to increase the scale of production as well as bio-security (Wang et al. 2014). The Poultry production cluster (PPC) is expected to encourage small-scale producers to become more intensive to meet the standards of good production and poultry health. Thus, this study was carried out to determine the diseases occurrence and the effectiveness in controlling infectious disease on the small producers of PPC and non-PPC.

\section{MATERIAL AND METHODS}

The study was carried out in 2012-2013. Data collection combined both quantitative and qualitative methods. It is comprised: semi structured questionnaires, observation of the biosecurity practice of poultry farms, and key informant interviews. Descriptive statistics were used to process the quantitative data and a content analysis was used to process the qualitative data.

\section{Data collection and sampling methods}

\section{Secondary data}

The secondary data was collected from government agencies related to livestock production and animal health. The research was also utilized existing sources of data and information about the study sites. The secondary data mainly included the statistical data on demographic information, socio-economic information, poultry populations, animal health and environmental indicators to trace and understand the development of poultry production clusters. Especially, it serves as a background for selection of the study sites and to identify the sampling frame.

\section{Primary data}

The primary data were collected from: (1) Small-scale poultry farmers; and from (2) Key informants in the communities, local officers and practitioners (veterinary staffs, extension workers). The key indicators are:

1. Epidemiological data: Type of poultry disease, prevalence of disease and death rate of poultries. 
2. Knowledge of farmers on disease control: Vaccination, disease management, drugs, chemicals and antibiotics use, cleaning system (clean - housing/equipment and changed cloth), veterinary service, monitoring disease system, transportation control, location, and farm area management (destroy chicken death system), record system (production, number of poultry, number of poultry sick, number of poultry death, etc.).

The following four types of tools used to collect primary information and data:

1. The semi structured questionnaires was mainly used to collect quantitative data, to demonstrate the evidence and the magnitude regarding bio-security practices and epidemiology data.

2. The focus group discussions was used with households in the study sites to collect the qualitative data to understand respondents' feelings, needs, and behaviors, especially people's perceptions on the environment and poultry health issues related to the PPC.

3. Epidemiology-related information was collected from local veterinary and technical services representative of the nucleus (company).

4. Triangulated check on information from different sources.

\section{Study site}

The study was conducted in West Java Province, Indonesia. Subang and Ciamis District were choosen to meet criteria for PPC which consist of small scale poultry farmers with poultry population 1,000-5,000 birds per household. In Subang, there are also poultry farmers who do not include in PPC establishment (i.e. non-PPC), poultry population per household are similar to those in PPC that is less than 5,000 birds. Both farmers in PPC and non-PPC in Subang District raised broiler, and farmers in PPC in Ciamis District raised male layers (Table 1).

Tabel 1. Location, number of PPC and non-PPC farms, average population and poultry species

\begin{tabular}{lcccc}
\hline \hline \multirow{2}{*}{ Location of study sites } & \multicolumn{2}{c}{ PPC farms } & \multicolumn{2}{c}{ non-PPC farms } \\
\cline { 2 - 5 } & $\mathrm{n}$ (average) & Poultry species & $\mathrm{n}$ (average) & Poultry species \\
\hline Subang District, West Java & $52(5,138)$ & Broiler & $31(4,577)$ & Broiler \\
Ciamis District, West Java & & & & \\
PPC1 & $51(2,854)$ & Male layers & NA & NA \\
PPC2 & $54(2,206)$ & Male layers & NA & NA \\
\hline
\end{tabular}

\section{RESULTS AND DISCUSSION}

Poultry production cluster (PPC) and non-PPC are different criteria for classifying smallholders' poultry farms. In PPC, the farmers form a cluster in an area, but farmers in non-PPC conduct their own farms which are distant to each other. No government's intervention that makes PPC and non-PPC different in term of production management. Partnership with a company or poultry shop (as nucleus) is conducted by both farmers (as plasm) in PPC and non- PPC. This pattern requires the nucleus supplies production inputs (DOC, feed, vaccine, medicines, and pens rehabilitation). The nucleus has the authority over operational management and diseases control through its technical service person in the pen location, and also responsible for product (live birds) marketing. In China, the cluster area provides various infrastructures such as roads, electricity, water supply and sewage treatment facilities (Wang et al. 2014). But there was no sewage treatment facility in PPC in the study area. 
Ilham et al. (2013) reported that the nucleus prefers farmers in PPC than in non-PPC due to larger business scale for better economic and technical efficiencies. The farmers in PPC will get better experience from the farmers in the cluster. Thus, the nucleus will be more profitable to partner with farmers in PPC. Poultry farms in clusters do not necessarily have better economic performance than those outside PPC. Many farmers in PPC only consider them to be an advantage for expanding the scale of their poultry operations and improving household incomes, and they are less concerned about and have limited capacities to enhancing biosecurity and environmental management (Wang et al. 2015). In general, no different profit gained by the farmers in PPC and non-PPC such as proven using the profit function (Ilham et al. 2013).

\section{Farmers' characteristics}

Farmers' characteristic is showed in Table 2. The average ages of the farmers were 45 to 50 years indicating that they are productive and experienced in managing the farming. Physically, the farmers were assisted by family labor and also by non-family labor. The family members per house hold in the study sites were three persons in average. The farmers who hire non-family labor for pen employees in Subang were $58 \%$ in PPC and $48 \%$ in non-PPC, while in Ciamis, in PPC1 (9\%), and PPC2 (13\%). Many farmers in Subang hired pen employees because they have other business activities. As a sub-urban area, there was more business activities with higher opportunity cost in Subang compared to Ciamis.

Table 2. Poultry farmers' characteristics in study sites

\begin{tabular}{|c|c|c|c|c|c|c|c|c|}
\hline \multirow{3}{*}{ Indicator } & \multicolumn{4}{|c|}{ Subang } & \multicolumn{4}{|c|}{ Ciamis } \\
\hline & \multicolumn{2}{|c|}{ PPC } & \multicolumn{2}{|c|}{ Non-PPC } & \multicolumn{2}{|c|}{ PPC1 } & \multicolumn{2}{|c|}{ PPC2 } \\
\hline & Mean & Std & Mean & Std & Mean & Std & Mean & Std \\
\hline Age (year) & 50.23 & 12.24 & 44.74 & 10.59 & 44.37 & 13.14 & 44.7 & 11.76 \\
\hline Education (year) & 9.06 & 3.43 & 9.81 & 3.82 & 9.14 & 2.84 & 6.43 & 1.50 \\
\hline $\begin{array}{l}\text { Training of poultry } \\
\text { raising (day) }\end{array}$ & 0.06 & 0.30 & 0.84 & 2.58 & 0.13 & 0.58 & 3.37 & 3.82 \\
\hline $\begin{array}{l}\text { Poultry farming } \\
\text { experience (year) }\end{array}$ & 7.60 & 6.02 & 9.87 & 5.82 & 7.81 & 7.08 & 9.20 & 5.34 \\
\hline $\begin{array}{l}\text { Working experience } \\
\text { at the company (year) }\end{array}$ & 0.60 & 2.59 & 0.45 & 1.55 & 2.59 & 6.43 & 2.13 & 4.13 \\
\hline $\begin{array}{l}\text { Total household's } \\
\text { member (persons) }\end{array}$ & 3.17 & 1.35 & 3.42 & 1.31 & 3.21 & 1.40 & 3.17 & 1.45 \\
\hline $\begin{array}{l}\text { Hiring pen's } \\
\text { employee }(\%)\end{array}$ & & & & & & & & \\
\hline \multicolumn{9}{|l|}{$\operatorname{Sex}(\%)$} \\
\hline Male & \multicolumn{2}{|c|}{98.11} & \multicolumn{2}{|c|}{100} & \multicolumn{2}{|c|}{74.6} & \multicolumn{2}{|c|}{51.85} \\
\hline Female & \multicolumn{2}{|c|}{1.89} & \multicolumn{2}{|c|}{0} & \multicolumn{2}{|c|}{25.4} & \multicolumn{2}{|c|}{48.15} \\
\hline
\end{tabular}

Education and working experiences in chicken farming were the important factors for making decisions and getting the best for raising the poultry farm. Education levels of the farmers range from 6 to 10 years or they just finished elementary school or junior high school. Education levels of the farmers were relatively low, in average were 9 years, 
except in PPC2 Ciamis is 6.43 years. Low educational level in PPC2 in Ciamis was caused most of the farmers as household mothers. Around $48 \%$ of the farmers in PPC2 Ciamis were women. However, administratively the partners registering with the nucleus/ companies were the husbands. Most of men or husbands work outside their home villages at other sectors, such as food crop farming and trade.

Farmers' experience of poultry farming was 7 to 10 years. Before running their own farms, some of them work at the poultry farms and get training in poultry agribusiness. The data showed that everage farmers' experience in working at others' poultry farms were lower than the standard deviations. It indicated that their experiences as workers at the poultry farms and as trainees in poultry agribusiness were quite various. The trainings are usually conducted by the technical service from the companies. Through trainings, the nucleus/companies expect the farmers' skill improved. Impacts of the training according to the nucleus/companies were low caused by relatively low educational background of the farmers. Jansen et al. (2009) suggested that older farmers were less likely to use multiple sources of information; however, more highly educated farmers are willing to use a variety of information sources as guidance to manage the farm.

\section{Animal health and diseases control activities}

Based on the poultry health aspect, the existance of PPC, where the poultry pens are located in one area will be easier in implementing all in - all out of chickens. Therefore, this should give PPC farms easy to apply biosecurity practice and a better chance of effectively controlling diseases. According to Tuan (2013) PPC farms should have better chance to access training course or workshop on disease prevention and production technique to update information and knowledge. Local authority often calls to the PPC farms before they call to other isolated farms. It is widely recognized that information about agricultural innovation diffuses mostly through household level relationships to networks of relatives and community links (Bandiera \& Rasul 2006; Katungi et al. 2007; Tatlonghari et al 2012). All farmers within a PPC should be able to easily and quickly share information about animal health and treatment method to avoid inter-transmission pathogens. However, prevention and disease control are part of the company's responsibilities, so the farmer efforts to prevent disease occurrence are not optimum of their capacity. The farmers tend to do not have any target to increase their poultry production, likewise in their effort to reduce the mortality rate.

For vaccination measures, Newcastle Disease (ND) and Infectious Bursal Disease (IBD) were the most regularly vaccinated diseases in poultry production (approximate 9095\%) of all farms. The proportion of PPC and non-PPC farms using vaccination against the two above mentioned diseases were approximately similar in both districts. The vaccination program for ND and IBD was done by the company as a nucleus and the farmer just need to execute it under the nucleus supervision. The vaccination program in study sites follows: (1) Newcastle Disease vaccine, at five days of age: Eye drops and killed vaccine sub-cutan, and at 18 days of age: Active vaccine through drinking water; and (2) Infectious Bursal Disease vaccine: There are two different time of application, at 11 to 12 days of age, or at 16 to 17 days of age.

There was no vaccination program for AI because there was no AI case reported. Antibiotic was sometime given especially to prevent and treat Chronic Respiratory Disease (CRD). The type of antibiotic and its application to chickens are set by the nucleus, so that the farmer does not know the appropriate antibiotic for the poultry. 


\section{Situation of poultry disease and mortality}

Recording of disease occurrence and mortality is very important for measuring the productivity. The company has suggested the farmers to record the sick and dead chickens. However, the numbers of farmers who do recording are few. Table 3 showed that farmers tend to record the mortality ( $85 \%$ in PPC and $90 \%$ in non-PPC, Subang), rather than record the incidence of the disease, which were less than 50\%. While in PPC2, Ciamis there were only two farmers who record disease occurrence $(3.70 \%)$ and there are only four farmers who record the mortality $(7.41 \%)$. Therefore, it was hard to trace the mortality and disease occurrence directly from the farmer. In consequence, the data must be re-confirmed to the technical service who works in each region.

Table 3. Number of farmers who record mortality and disease occurance

\begin{tabular}{lcccc}
\hline \hline \multirow{2}{*}{ Indicator (\%) } & \multicolumn{2}{c}{ Subang } & \multicolumn{2}{c}{ Ciamis } \\
\cline { 2 - 5 } & PPC $(\mathrm{n}=52)$ & Non-PPC $(\mathrm{n}=31)$ & $\mathrm{PPC} 1(\mathrm{n}=51)$ & $\mathrm{PPC}(\mathrm{n}=54)$ \\
\hline Recording diseases occurance & 41.51 & 12.9 & 42.86 & 3.70 \\
Recording mortality of poultry & 84.91 & 90.32 & 66.67 & 7.41 \\
\hline
\end{tabular}

The result showed that the mortality rate of chickens in all PPC and non-PPC was less than $5 \%$ per cycle (Table 4). The length production cycle seemed to be not having an impact on mortality rate. There was an interval between one cycle to the next cycle which is varies between 2 to 4 weeks. In this time interval farmers cleaning and disinfects the poultry pens.

Table 4. Population, mortality rate, number of day per-production

\begin{tabular}{lcccc}
\hline \hline \multirow{2}{*}{ Indicator } & \multicolumn{2}{c}{ Subang } & \multicolumn{2}{c}{ Ciamis } \\
\cline { 2 - 5 } & PPC* & Non-PPC* & PPC1** & PPC2** \\
\hline Number of days/production cycle & 31.55 & 30.39 & 47.46 & 51 \\
Number of cycle/year & 5 & 6 & 4.3 & 3.7 \\
Number of poultry/cycle (in average) & 272,900 & 142,900 & 146,222 & 119,000 \\
Mortality rate/cycle (\%) & 4.57 & 3.76 & 3.63 & 3.06 \\
\hline
\end{tabular}

*Broiler; **Male layer

The prevalence rate of slow growth sindrome was less than 3\%, with a range of 0.92 to $2.77 \%$ (Table 5) and the mortality rate less than $2 \%$. However, farmers concerned with the clinical sign of the syndrome, as the size of chickens in one flock varies, weight gain was slow or retarded, wing tips may be curled, the legs and beak of affected chickens may appear pale in color. Smart et al. (1990) stated that clinical symptom of slow growth syndrome often compounded by external factor, such as stress caused by not optimal heating in the first week; since low brooding temperatures have been shown to worsen the effects of the syndrome.

The average prevalence of slow growth of male layer (in PPC1 and PPC2) was higher than the prevalence rate of broiler (in PPC and non-PPC). This corresponds to Zavala \& Barbosa (2006) statement that male chickens were more severely affected than females, and certain strains of chickens appear to be more susceptible to the effects of slow growth syndrome. In contrast, Wahyuwardani et al. (2000) reported that slow growth cases did not different between strain, as eight chicken strains which were observed from 13 regencies 
in West Java and Central Java Province were susceptible. Furthermore, the weight of broiler observed with slow growth syndrome only reached $20-40 \%$ compare to the normal chickens in the same age, and the incidence rate varies with the range of 0.1 to $50 \%$.

Table 5. Prevalence rate of slow growth syndrome in the study site (\%)

\begin{tabular}{lcccc}
\hline \hline \multirow{2}{*}{ Indicator } & \multicolumn{2}{c}{ Subang } & \multicolumn{2}{c}{ Ciamis } \\
\cline { 2 - 5 } & $\begin{array}{c}\text { PPC } \\
\text { POP = 272,900 }\end{array}$ & $\begin{array}{c}\text { Non-PPC } \\
\text { POP = 142,900 }\end{array}$ & $\begin{array}{c}\text { PPC1 } \\
\text { POP = 146,222 }\end{array}$ & $\begin{array}{c}\text { POP } ~ \\
\text { POP 119,000 }\end{array}$ \\
\hline Cycle 1 & 1.81 & 0.83 & 4.95 & 1.90 \\
Cycle 2 & 1.76 & 0.80 & 4.21 & 3.09 \\
Cycle 3 & 1.47 & 0.90 & 3.03 & 4.05 \\
Cycle 4 & 1.77 & 0.87 & 1.47 & 2.83 \\
Cycle 5 & 1.92 & 1.20 & 0.02 & 2.01 \\
\hline Average (\%) & 1.75 & 0.92 & 2.74 & 2.77 \\
\hline
\end{tabular}

Slow growth is a multi-factorial syndrome, the cause can be grouped in three major categories, and those are slow growth due to: (1) Disease or infectious agent; (2) Error in management and DOC quality; and (3) Lack of nutrition and food (Infovet 2008). When the slow growth is caused by disease or pathogenic agents, then one of the main characteristic of the syndrome will be repeated from period to period. The age variation on broiler flock with short production cycle was also the factor that cause slow growth syndrome (Infovet 2008), moreover it worsen by poor management espesially the brooding systems in small-scale farmer, DOC quality with omphalitic and yolk-sac infection. In controlling the slow growth syndrome, Payne (2008) suggested to focus on three main things: bio-security, poultry sheds management, and vaccination.

Figure 1 shows trend of prevalence rate of slow growth syndrome for five cycles. The prevalence rate of broiler (PPC and non-PPC in Subang) relatively stable, while in male layer (PPC1 and PPC2, Ciamis) in the first cycle was relatively higher than another PPC, but the prevalence tend to decrease after the third cycle. Over all, the prevalence of slow growth syndrome was less than $5 \%$, and tends to decline or stable; this indicated that the cause of growth syndrome in these study sites was not due to infectious agent, but poor management practices at the farmer level.

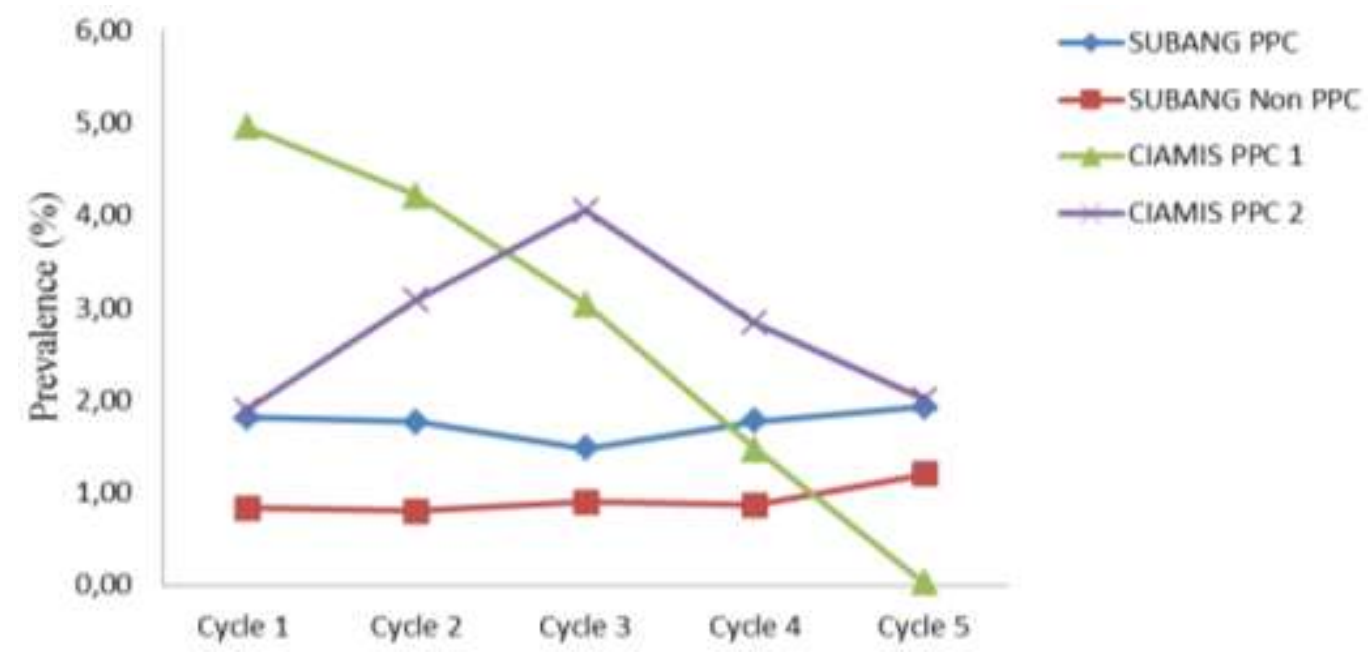

Figure 1. Prevalence pattern of slow growth syndrome for five cycles 
The viral disease that was frequently reported by farmers was IBD and ND, and there was no report on AI. The ND and IBD prevalence for five cycles were relatively low on the range of no more than one percent, and there was no report of ND in PPC2 Ciamis (Tabel 6). In Subang the case fatality rate of ND (mortality/death due to ND) in PPC and non-PPC was up to $46-98 \%$ and in PPC1 Ciamis was less than 50\%. This was in accordance with Awan (1994) that incident of ND can reach up to $100 \%$ with case fatality rate of $90 \%$. The morbidity and mortality of ND varies depend on the virulence of virus strain and poultry susceptibility. Furthermore, the environment condition, secondary infection, vaccination history, and poultry species will affect these numbers. Padmawati \& Nichter (2008) stated that the broiler business is profitable, but risky. On average 5-10\% of birds are lost to illness, most notably Newcastle's disease. Farmers spoke of birds being especially vulnerable to illness during times of climate transition (October/November from dry to rainy season, and May/June - rainy to dry season) and expected that more birds would be lost at this time.

Table 6. Prevalence and mortality of ND and IBD for five cycles

\begin{tabular}{|c|c|c|c|c|}
\hline \multirow[b]{2}{*}{ Indicator } & \multicolumn{2}{|c|}{ Subang } & \multicolumn{2}{|c|}{ Ciamis } \\
\hline & $\begin{array}{c}\text { PPC } \\
\text { Pop }=272,900\end{array}$ & $\begin{array}{c}\text { Non-PPC } \\
\text { Pop }=142,900\end{array}$ & $\begin{array}{c}\text { PPC1 } \\
\text { Pop }=146,222\end{array}$ & $\begin{array}{c}\text { PPC2 } \\
\text { Pop }=119,000\end{array}$ \\
\hline \multicolumn{5}{|c|}{ Newcastle Disease (ND) } \\
\hline \multicolumn{5}{|c|}{ Prevalence $(\%)$} \\
\hline Cycle 1 & 0.19 & 0.86 & 1.01 & 0.00 \\
\hline Cycle 2 & 0.20 & 0.27 & 0.55 & 0.00 \\
\hline Cycle 3 & 0.29 & 0.27 & 0.23 & 0.00 \\
\hline Cycle 4 & 0.24 & 0.26 & 0.11 & 0.00 \\
\hline Cycle 5 & 0.38 & 0.26 & 0.03 & 0.00 \\
\hline \multicolumn{5}{|c|}{ Case fatality rate $(\%)$} \\
\hline Cycle 1 & 92.09 & 98.38 & 28.83 & 0.00 \\
\hline Cycle 2 & 91.70 & 89.64 & 31.01 & 0.00 \\
\hline Cycle 3 & 91.34 & 80.94 & 39.39 & 0.00 \\
\hline Cycle 4 & 93.31 & 65.75 & 32.69 & 0.00 \\
\hline Cycle 5 & 78.13 & 46.32 & 43.14 & 0.00 \\
\hline \multicolumn{5}{|c|}{ Infectious Bursal Disease (IBD) } \\
\hline \multicolumn{5}{|c|}{ Prevalence $(\%)$} \\
\hline Cycle 1 & 0.36 & 0.31 & 1.10 & 1.13 \\
\hline Cycle 2 & 0.59 & 0.35 & 0.66 & 0.84 \\
\hline Cycle 3 & 0.45 & 0.22 & 0.71 & 0.35 \\
\hline Cycle 4 & 0.40 & 0.21 & 0.39 & 0.26 \\
\hline Cycle 5 & 0.56 & 0.40 & 0.04 & 0.54 \\
\hline \multicolumn{5}{|c|}{ Case fatality rate $(\%)$} \\
\hline Cycle 1 & 62.29 & 92.36 & 49.84 & 18.59 \\
\hline Cycle 2 & 77.65 & 95.23 & 56.15 & 6.00 \\
\hline Cycle 3 & 69.78 & 93.31 & 36.56 & 10.36 \\
\hline Cycle 4 & 73.08 & 91.50 & 55.24 & 15.87 \\
\hline Cycle 5 & 74.77 & 47.03 & 36.92 & 13.91 \\
\hline
\end{tabular}


Prevalence rate of IBD in all PPC and non-PPC relatively low (0.04-1\%), and case fatality rate for five cycles is vary between 6.0 to $95 \%$ (Table 6). Case fatality rate of IBD in non-PPC up to four cycles is relatively high about $90 \%$. Prevention and control of IBD must include effective vaccination on breeder, bio-security programme and vaccination on broiler. Immunization program on breeder is an important part, because the maternal antibody will protect the chick to fight IBD (Butcher \& Miles 2009).

The pattern of ND and IBD cases was showed in Figure 2A and 2B. Newcastle disease often occurs once or twice a year on a regular basis; it shows that the virus is endemic and commonly occurs seasonally. In Pakistan, diversified diseases are prevalent in both broilers and layers, overall incidence of ND was found as the highest (Abbas et al. 2015). The research result of Okwor \& Ezen (2010) in Nigeria shows ND prevalence in dry season period was high (November to February) and the prevalence was also relatively high in the peak of rain season (period of June to July). Poultry stress due to environment condition associated with dry and rain season period became the main factor and aggravates the disease condition in Nigeria. It was suggested that to control and eradicate ND should include poultry sheds and tools disinfection, suspend of the next DOC for 30 days, pest control such as bugs and rats, limit the human traffic (in and out), and avoid interaction with any other animal which health status was unknown.
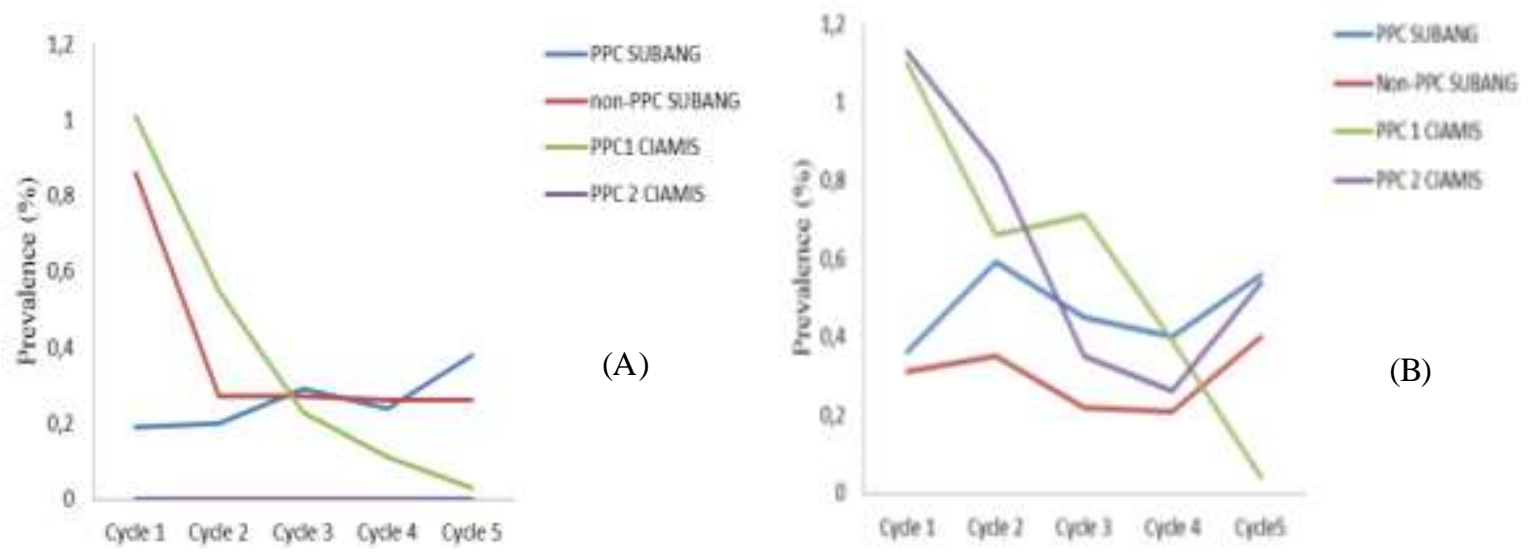

Figure 2. (A) Prevalence pattern of ND cases for five cycles in study sites; (B) Prevalence pattern of IBD cases for five cycles in study sites

Farmers in the study sites recognize the clinical signs of cronic respiratory disease (CRD) on poultry such as abnormal respiratory, sound in the trachea, fluid discharged from the eyes and nose. This disease is caused by Mycoplasma gallisepticum and $M$. synoyiae, and called as Mycoplasmosis. The prevalence of CRD in male layer (PPC2, Ciamis) was higher, range between 10 to 15 compare to the others PPC and non-PPC farms (Figure 3). The Figure showed that the pattern of CRD occurrence in male layer, PPC1 and PPC2 was similar. The CRD occurrence in broiler PPC and non-PPC also have consistence pattern.

Mycoplasmosis (CRD) in study sites usually occurs in 4-week of age. This results agreed with Hicham sid and Oumouna (2012) that outbreak of CRD in broiler flocks usually occured after four weeks of age; If the mortality rate of mycoplasmosis was high, complications may occur in presence of other agents such as ND, Corryza (Snot), Infectious Bronchitis (IB) and Escherichia coli. Mycoplasmosis (CRD) is transmitted vertically from the infected parent stock to the chicks. Horizontal transmission may occurs through direct contact from a group of poultry which clinically ill or a carrier which is under recovery phase to susceptible poultry (Shane 1998). Some factors which may affect the mycoplasmosis include: Transmission, the dose of infection-causing agent, 
environmental factor and stress such as temperature and ammonia concentration, age and poultry type (Ley \& Yoder 1997). According to Hicham \& Oumouna (2012) Mycoplasmosis was one of the most economically important disease in poultry, leads to loss due to mortality, medications expenses, and carcass condemnation for broiler.

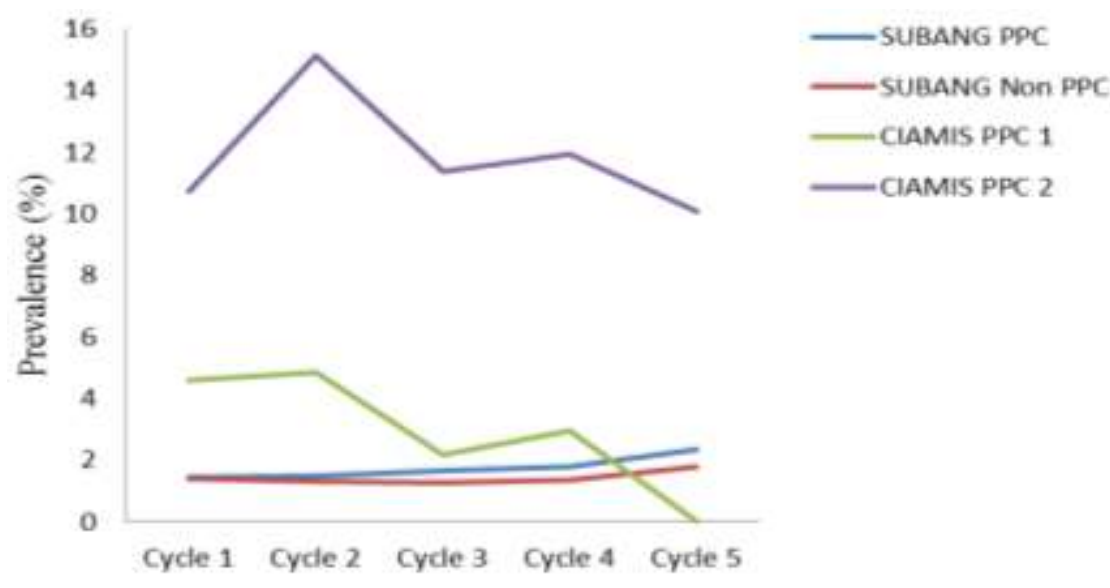

Figure 3. Prevalence pattern of CRD for five cycles in study sites

Diarrhea case in non-PPC Subang was higher than in other location, with prevalence rate range $2-4.5 \%$, the highest occurrence was in cycle three and four. Case fatality rate for diarrhea in PPC Subang was about $50 \%$, while in other three sites were varies between 20 to $40 \%$ (Table 7). The agents that may cause diarrhea were parasites (coccidia, worm), bacteria (E. coli, Salmonella sp), and some viruses such as ND and IBD. Accurate diagnosis is important to treat diarrhea appropriately. Treatment for virus causative agent is help to suppress secondary bacterial infection. Recent study on prevalence of poultry diseases in Bangladesh, conducted by Hassan et al. (2016) revealed that the most diseases encountered in layers were bacterial diseases $52.29 \%$, while in case of broilers the highest were viral diseases (53.24\%). Among the diseases, salmonellosis is most prevalent diseases followed by IBD and CRD in different kinds of poultry in Bangladesh.

Generally, the results indicated that disease frequently found in PPC were slow growth syndrome and CRD, in low level, except for PPC2 with prevalence rate of CRD reached $15 \%$, while in non-PPC was dominated by diarrhea. There was no disease outbreak during the five cycle observation; however it still needs to be alert by implementing the biosecurity to avoid losses. Martindah et al. (2014) assessed biosecurity practiced in this study site; the study showed that individual farmers in both clustered and non-clustered poultry farms did not apply biosecurity standard operational procedures (SOP) in optimal ways. Some biosecurity activities are management changes, which may be low cost but require commitment from owners and farm workers to implement successfully (Susilowati et al. 2012). These include allocating a specific worker to a shed and not allowing staff to move from shed to shed.

A study on an ecohealth assessment of poultry production clusters (PPCs) conducted by Wang et al (2015) revealed that the level of biosecurity in PPCs was found to be low due to socioeconomic factors and poor incentives for farmers to apply strict biosecurity measures. There are many risk behaviors of farmers in transmited diseases in poultry such as not reporting any incidence of sudden deaths of poultry, handling dead birds incorrectly, eating a sick chicken, eating raw egg yolk, and never used protection (gloves, masks, boots) when interacting with their poultry (Sukoco \& Pranoto 2012). In Nepal, bio-security policy can be formulated with the participation of stakeholder, and it would give new dimensions towards poultry farming in different clusters (Sharma 2010). However, to 
develop successful interventions, Aboud \& Singla (2012) suggested that it is critical to understand the perspective of the farmers to identify which behaviours to target and how to change them. Since it is difficult to change the behaviour by simply telling farmers to apply biosecurity as in SOP for daily practice.

Tabel 7. Prevalence and Case fatality rate of diarrhea for 5 cycles in study sites

\begin{tabular}{lcccc}
\hline \hline \multirow{2}{*}{ Cycles } & \multicolumn{2}{c}{ Subang } & \multicolumn{2}{c}{ Ciamis } \\
\cline { 2 - 5 } & PPC & Non-PPC & PPC1 & PPC2 \\
\hline Prevalence (\%) & 0,78 & 2,19 & 1,6 & 0,98 \\
Cycle 1 & 0,68 & 2,23 & 1,17 & 2,75 \\
Cycle 2 & 0,71 & 4,52 & 1,23 & 1,18 \\
Cycle 3 & 0,67 & 4,49 & 0,45 & 1,18 \\
Cycle 4 & 0,74 & 2,17 & 0,04 & 0,38 \\
Cycle 5 & & & & \\
Case fatality rate (\%) & 56 & 25 & 38 & 39 \\
Cycle 1 & 53 & 50 & 92 & 23 \\
Cycle 2 & 52 & 30 & 37 & 38 \\
Cycle 3 & 54 & 28 & 39 & 25 \\
Cycle 4 & 54 & 47 & 42 & 20 \\
Cycle 5 & & & & \\
\hline
\end{tabular}

\section{CONCLUSION}

Farmers within a PPC should be able to easily and quickly share information about animal health and treatment method to avoid inter-transmission pathogens. However, prevention and disease control are part of the companies, so the farmer efforts to prevent disease occurrence were not of their capacity. The level of diseases occurrence and mortality rate in both PPC and non-PPC was similar with a few variations. The disease frequently found in PPC were slow growth syndrome and CRD in low level, except for PPC2 with prevalence rate of CRD reached $15 \%$, while in non-PPC was dominated by diarrhea.

Education and working experiences in chicken farming were the important factors for making decisions and getting the best for raising the poultry farm. Farmer's experiences at the poultry farms were quite various. It was suggested that the incidence of the disease occurrence should be reduced by encourage of farm workers in PPC and non-PPC to implement some basic principle of biosecurity.

\section{ACKNOWLEDGEMENT}

This study is funded through a capacity building initiative for Ecohealth Resarch on Emerging Infectious Disease in Southeast Asia supported by the International Development Resaerch Centre (IDRC), the Canadian International Development Agency (CIDA) and the Australian Agency for International Development (AusAID) in partnership with the Global Health Resaerch Initiative. 


\section{REFFERENCES}

Abbas G, Khan SH, Hassan M, Mahmood S, Naz S, Gilani SS. 2015. Incidence of poultry diseases in different seasons in Khushab District, Pakistan. J Adv Vet Anim Res. 2:141-145.

Aboud FE, Singla DR. 2012. Challenges to changing health behaviours in developing countries: A critical overview. Soc Sci Med. 75:589-594.

Adjid RMA, Indriani R, Damayanti R, Aryanti T, Darminto. 2006. Dukungan teknologi veteriner dan strategi pengendalian penyakit unggas (ayam) di sektor 3 dan 4. Dalam: Subandriyo, Diwyanto K, Kompyang IP, Setioko AR, Ketaren PP, Suparyanto A, Priyanti A, penyunting. Prosiding Lokakarya Nasional Inovasi Teknologi dalam Mendukung Usaha Ternak Unggas Berdayasaing. Semarang, 4 Agustus 2006. Bogor (Indonesia): Puslitbangnak. hlm. 22-27.

Aengwanich W, Intarakhamhaeng M, Wandee J, Nongbua T, Chaiyasak S, Srikot P, Thammasar K, Junsanitsri N, Sritongtuam K, Tawinwaang T. 2012. Poultry production clusters (PPCs) after AI outbreaks in Thailand: Past, present and future direction. Int J Poult Sci. 11:541-550. DOI: http://dx.doi.org/10.3923/ijps.2012.541.550

Aengwanich W. 2014. Farm models and eco-health of poultry production clusters (PPCs) following avian influenza epidemics in Thailand. Sustainability. 6:2300-2319.

Awan MA, Otte M J, James AD. 1994. The epidemiology of newcastle disease in rural poultry: A review. Avian Pathol. 23:405-423.

Bandiera O, Rasul I. 2006. Social networks and technology adoption in Northern Mozambique. Econom J. 116:869-902.

Butcher GD, Miles RS. 2009. Infectious bursal disease (gumboro) in commercial broilers. Document VM84, one of a series of the Veterinary Medicine-Large Animal Clinical Sciences Department, Florida Cooperative Extension Service. Florida (US): Institute of Food and Agricultural Sciences, University of Florida.

Ditjen PKH. 2013. Statistik peternakan dan keehatan hewan 2013. Jakarta (Indonesia): Direktorat Jenderal Peternakan dan Kesehatan Hewan, Kementerian Pertanian.

Hassan K, Kabir H, Abdullah A, Sultana S, Khokon SI, Kabir SML. 2016. Prevalence of poultry diseases in Gazipur District of Bangladesh. Asian J Med Biol Res. 2:107-112. DOI: 10.3329/ajmbr.v2i1.27575

Hicham S, Oumouna M. 2012. Avian mycoplasmosis is a continuing economic challenge. World Poul. 28.

Ilham N, Yusdja Y, Basuno E, Martindah E, Sartika RAD. 2013. Ecohealth assesment on poultry production clusters for the livehood of improvement small producers. Final report. Bogor (Indonesia): Indonesia Center for Sosio-Economic and Agriculture Policies. Indonesian Agency for Agricultural Reserch and Development. Ministry of Agriculture - Republic of Indonesia collaboration with International Development Research Centre (IDRC) - Canada.

Ilham N. 2015. Kebijakan pemerintah terhadap usaha unggas skala kecil dan kesehatan lingkungan di Indonesia. Wartazoa. 25:95-105. DOI: http://dc.doi.org/10.14334/wartazoa.v25i2.1146

Infovet. 2008. Classic problem remains disturbing, Focus. INFOVET, Ed. 182.

Jensen KL, English BC, Menard, RJ. 2009. Livestock farmers' use of animal or herd health information sources. J Extension. 47:1-10.

Katungi E, Edmeades S, Smale M. 2008. Gender, social capital and information exchange in rural Uganda. J Int Dev. 20:35-52.

Ley DH, Yoder HWJr. 1997. Mycoplasma gallisepticum infection. In: Calnek BW, Barnes HJ, Beard CW, McDougald LR, Saif YM, editors. Diseases of poultry. $10^{\text {th }}$ Ed. London (UK): Mosby-Wolfe. p. 194-207. 
Martindah E, Ilham N, Basuno E. 2014. Biosecurity level of poultry production cluster (PPC) in West Java, Indonesia. Int J Poult Sci. 13:408-415.

Okwor EC, Eze DC. 2010. The annual prevalence of newcastle disease in commercial chickens reared in South Eastern savannah zone of Nigeria. Res J Poult Sci. 3:23-26.

Padmawati S, Nichter M. 2008: Community response to avian flu in Central Java, Indonesia. Anthropol Med. 15:31-51.

Payne J. 2008. Runting-stunting syndrome in broilers. Timely Topic Newsletter. Vol.7. 5 June 2008.

Shane SM. 1998. A Handbook of Poultry Diseases. American Soybean Association. Singapore. Unite Soybean Board.

Sharma B. 2010. Poultry production, management and bio-security measures. J Agric Environ. 11:120-125.

Smart IJ, Barr DA, Reece RJ, Forsyth WM, Ewing I. 1988. Axperimental reproduction of runting and stunting syndrome of broiler chickens. Avian Pathol. 17:617-621.

Sukoco NEW, Pranata S. 2012. Perilaku berisiko peternak unggas dan kejadian flu burung di Desa Mojotamping, Kecamatan Bangsal, Kabupaten Mojokerto, Provinsi Jawa Timur. Bul Penelitian Sistem Kesehatan. 15:47-54.

Susilowati SH, Patrick I, Iqbal M, Jubb T. 2013. The characteristics of the farm and the farmer that affect the adoption of biosecurity on smallholder poultry farms in Indonesia. Livest Res Rur Dev. 25:2013.

Tatlonghari G, Paris T, Pede V, Siliphouthone I, Suhaeti R. 2012. Seed and information exchange through social networks: The case of rice farmers of Indonesia and Lao PDR. Sociol Mind. 2:169-176.

Tuan AND. 2013. Eco-health assessment on poultry production clusters (PPCs) for the livelihood improvement of small producers. Research report. Hanoi (Vietnam): The Centre for Agricultural Policy, Institute of Policy and Strategy for Agriculture and Rural Development.

Wahyuwardani S, Sani Y, Parede L, Syafriati T, Poeloengan M. 2000. Stunting or runting syndrome in broilers and description of pathology. JITV. 5:1-7.

Wang L, Liu Q, Zheng HE, Wu J, Li X. 2014. Development of poultry production clusters in China: A policy review. Int J Poult Sci. 13: 292-298.

Wang L, Basuno E, Nguyen T, Aengwanich W, Itham N, Li X. 2015. An ecohealth assessment of poultry production clusters (PPCs) for the livelihood and biosecurity improvement of small poultry producers in Asia. Infect Dis Poverty. 4:2015. DOI: 10.1186/2049-9957-4-6. eCollection 2015. http $/ / \mathrm{www}$.idpjournal.com/content/4/1/6. Acces on 8/4/2016.

Zavala G, Barbosa T. 2006. Runting and stunting in broiler chickens. Apinco-Facta [Internet]. [Cited 26 January 2013]. Available from: http://www.poultryhealth.com/fora/inthelth/zavala _apinco_06 